\title{
An empirical study of buyer-supplier relationships in the Taiwanese machine tool industry
}

\author{
C.C. Yeh and C.F. Chen* \\ Department of Business Management, National Taipei College of Business, \\ No. 321, Sec. 1, Jinan Rd., Zhongzheng District, Taipei City 100, Taiwan (R.O.C.) \\ ychinc@webmail ntcb.edu.tw; mark0617@ms7 hinet net
}

Received January 2011

\begin{abstract}
Machine tools are an essential component of advanced manufacturing technology, and the machine tool industry in Taiwan dominates the world market. However, Taiwanese machine tool plants are unique, in that approximately $62 \%$ of the total operating cost for a plant arises from its suppliers. This paper examines buyer-supplier relationships in the Taiwanese machine tool industry. In doing so, a theoretically relevant set of buyer-supplier relationship variables is identified from the literature. Factor analysis shows that buyer-supplier relationships are a two dimensional construct containing the core dimensions of a purchasing cooperative relationship and an R\&D cooperative relationship. Connections between buyer-supplier relationships and manufacturing performance (quality, cost, delivery and flexibility) are then examined. This study reveals that buyer-supplier relationships are related to overall manufacturing performance, but can vary depending on the dimensions of the relationships. Finally, some discussions are presented and managerial implications are made for the industry.
\end{abstract}

\section{Introduction}

Working under the intensely competitive conditions of the global market, the Taiwanese machine tool industry as a whole ranks first worldwide, with approximately a $15 \%$ share of the global market. In 2006, Taiwan ranked sixth globally in the production of precision tools, with a total production value of Taiwan Dollar (TWD) 126 billion. Regarding exports, Southeast Asia has already replaced China as the area with the largest number of suppliers. According to the Ministry of Finance, R.O.C. (2011), Taiwan's export volume for precision tools in 2010 grew $34.8 \%$ from 2009. After financial tsunami, the ranking of Taiwanese import and export is increasing continually (World People News, Sep 16, 2010).

The machine tool industry in Taiwan dominates the world market. However, Taiwanese machine tool plants are unique, in that approximately $62 \%$ of the total operating cost for a plant arises from its suppliers Mechanical Industry Research Laboratories (MIRL), (1998). Therefore, plants need to further reduce the costs from their suppliers so as to achieve a distinct competitive performance. For this reason, plants have developed cooperative buyersupplier relationships with these suppliers to enhance their own advantage.

This study is important because it demonstrated the impact of buyer-supplier relationships on the company's manufacturing performance and could be used to advance the practices of buyer-supplier relationships. The purpose of this research was two-fold. The first was to identify the key dimensions of buyer-supplier relationships. The second was to attempt to understand how these buyer-supplier relationships affect manufacturing performance of the machine tool industry in Taiwan.

\section{Identification of key constructs}

According to Samson Wong's study (2005), there are two two-directional relationships, between suppliers and buyers, and suppliers and local supply firms (subsuppliers). Therefore, there are a total of four directional flows among the three types of firm. It is pointed out there are total of four directional flows among the three types of firms: (1) from the buyer toward the supplier; (2) from the supplier toward the sub-suppler; (3) from the supplier toward the buyer; and (4) from the sub-supplier toward the supplier. Hsieh (2004) showed how commitment, coordination and information sharing produce positive effects on the establishment of a long-term buyer-supplier partnership and that a powerful buyer-supplier partnership is helpful in achieving improved operational performance. A long-term partnership between the buyer and supplier increases the intensity of buyer-supplier coordination (Toni \& Nassimbeni, 1999). Through a well-developed long-term relationship, a supplier becomes part of a well-managed supply chain, which will have a lasting effect on the competitiveness of the entire supply chain (Choi \& Hartley, 1996). However, perhaps many organizations find they can get the Just-in-time (JIT) results desired by entering into regular long-term relationships, and these long-term relationships can be extremely complicated to develop and manage, and therefore may not be universally desirable (Ellram, 1995). 
The development of partnerships with suppliers is viewed as a positive use of the buying firm's power and can be used to motivate suppliers to cooperate, but this can be a challenge (Monczka \& Morgan, 1993). According to Carr and Pearson (1999), investigate the impact of 'strategic purchasing' on 'buyer-supplier relationships' and the subsequent impact of 'buyer-supplier relationships' on the 'firm's financial performance'. Moreover, Shin, Collier and Wilson (2000) found that supplier development affects the buying firm's cost and delivery performance. A key part of the buyer-supplier relationship is involvement, which gives suppliers responsibility for product development (Dyer \& Ouchi, 1993).

JIT is a management philosophy that was originally applied by the Japanese in the early 1970s in a large number of manufacturing enterprises. It showed a need to revise traditional supply relationships to create buyer-supplier partnerships for profit creation rather than traditional adversarial and competitive relationships (Steyn \& Toit, 2010; Toni \& Nassimbeni, 1999). Scannell, Vickery and Droge (2000) explained that the reduction of inventory, delivery lead-time and incremental cost improvements of scheduling flexibility and quality are the important benefits of JIT purchasing.

Wagner and Krause (2009) pointed out the formation of supply chains, networks and buyer-supplier relationships necessitate a reconsideration of the communication, behavior and skill sets of the individuals involved in managing supplier relationships. Information sharing is a key attribute of buyer-supplier relationships (Ellram \& Hendrick, 1995). Ellram (1995) suggested that facets of two-way communication include computer linkages, corporate communication, information sharing and understanding and operational information. Levy (2008) mentioned that direct communication with suppliers inevitably solves problems in the buying firm's product development process.

1

Quality is one of the most important performance criteria used in the selection and evaluation of suppliers (Choi \& Hartley, 1996), who stated that: (1) supplier quality is a critical determinant for overall product quality and cost, as is (2) the supplier's quality control system, and (3) the supplier's technological capabilities and management systems.

Moreover, Kekre, Murthi and Srinivasan (1995) suggested that firms have discarded the traditional practice of using several supply sources and favor a drastic reduction in sources. The reduced number of suppliers implies a number of advantages. De Toni and Nassimbeni (1999) found that supply-based reduction policies are positively related to the buyer-supplier product design. Shin et al. (2000) found that reducing the number of suppliers could improve competitive performance in the supply chain.

\section{Research methodology}

A buyer's plant was chosen as the subject of analysis, since the JIT purchasing practices analyzed are implemented at the plant level. The target respondents for the survey were the plant managers of certain machine tool plants in Taiwan. Research suggests that greater attention to informant selection can help overcome common method variance problems when practical considerations require single respondents (Miller \& Roth, 1994). This study targeted the plant managers to assure that respondents were knowledgeable of buyer-supplier relationships and the manufacturing performance of their companies relative to their competitors. A list of 120 potential respondents was drawn from the Taiwan machinery directory. Each company was contacted by phone after the questionnaire was mailed to ensure it had been received. The plants that agreed to take part were visited to gather qualitative information about the buyer-supplier relationships that were in practice at the time. Of the 120 potential respondents, 12 were no longer at the address indicated. A total of 66 questionnaires were received from the remaining 108 respondents, with a response rate of $62 \%$. Of these respondents, $16.64 \%$ were from plants with more than 401 employees, and $36.36 \%$ were from plants with capital of more than NTD 60 million. The distribution of the respondents of the plants surveyed indicated that all of the large plants in Taiwan were included in the sample. The geographical distribution of the plants indicated that more than $80 \%$ were located in central Taiwan.

The buyer-supplier relationship was measured using seven scale items (survey questions) that were adapted from previous literature and from suggestions by academics and industry experts. They were measured using a seven-point scale ranging from 'Strongly Disagree' (1) to 'Strongly Agree' (7). Four dimensions of manufacturing performance were measured in this study: quality, cost, delivery and flexibility. Given the multi-dimensional nature of these performances, multiple items were used to capture the firm's performance relative to major competitors. The survey instrument was modified and pre-tested on several plant managers before being finalized. The respondents were also asked to provide a seven-point rating, ranging from 'poor' (1) to 'excellent' (7), of the firm's performance relative to its major competitors for each item.

In this study, it uses factor analysis to test each items (variables). Factor loadings are the correlation of each variable and the factor. Loadings indicate the degree of correspondence between the variable and the factor, with higher loadings making the variable representative of the factor. Factor loadings are the means of interpreting the role each variable plays in defining each factor. 


\section{Results}

\section{The dimensions of buyer-supplier relationships}

Table 1 shows the extent of agreement of the seven buyersupplier relationships items. As can be seen, the items were all significantly correlated with one another. However, the magnitudes of the correlations were not sufficiently high enough to suggest that these seven buyer-supplier relationships items were different but related phenomena.

Using the seven buyer-supplier relationship items as input, principal component factor analysis with varimax rotation was performed. The objective was to determine which of the items could be grouped together to reflect the core underlying dimensions of buyer-supplier relationships. Factor analysis revealed a stable two-factor solution, with each of the factors having an eigenvalue greater than 1 (Gorton et al., 2008). The cumulative percentage of the total variance explained due to these two factors was $90.5 \%$. Table 2 presents the results of the factor analysis. Since the factor loading of the measure 'reduced number of suppliers' was relatively low, it was removed from the final buyer-supplier relationships construct.
The first factor, purchasing cooperative relationships, consisted of the following four measures: long-term relationships, open communication and information sharing, quality a focus of selecting suppliers, and JIT purchasing. The second factor, $R \& D$ cooperative relationships, consisted of the following two measures: supplier development and supplier involvement in product development.

The items comprising each factor in Table 2 were analyzed separately to verify the unidimensionality. Reliability analyses were conducted using Cronbach standardized alphas. The Cronbach alphas for factor 1 (purchasing cooperative relationship) and factor 2 (R\&D cooperative relationship) were 0.7749 and 0.7912 , respectively. These analyses strongly supported the unidimensionality and reliability of the two buyer-supplier relationship constructs.

\section{Predicting manufacturing performance}

A separate factor analysis was conducted on the performance ratings of the sixteen manufacturing performances, and the results are provided in Table 3.

Table 1: Correlation among buyer-supplier relationships

\begin{tabular}{|c|c|c|c|c|c|c|c|}
\hline Items (Variables) & (R1) & (R2) & (R3) & (R4) & (R5) & (R6) & (R7) \\
\hline Long-term relationship (R1) & 1,000 & & & & & & \\
\hline Long-term relationship (R2) & $0,414^{* *}$ & 1,000 & & & & & \\
\hline $\begin{array}{l}\text { Supplier involvement in product } \\
\text { development }(\mathrm{R} 3)\end{array}$ & 0,038 & $0,518^{* *}$ & 1,000 & & & & \\
\hline JIT purchasing (R4) & $0,494^{* *}$ & $0,360^{* *}$ & $0,285^{*}$ & 1,000 & & & \\
\hline $\begin{array}{l}\text { Open communications and information } \\
\text { sharing (R5) }\end{array}$ & $0,431^{* *}$ & $0,496^{* *}$ & $0,262^{*}$ & $0,417^{*}$ & 1,000 & & \\
\hline Quality focus in selecting suppliers (R6) & $0,436^{* *}$ & $0,332^{* *}$ & 0,107 & $0,325^{*}$ & $0,420^{* *}$ & 1,000 & \\
\hline Reduced number of suppliers (R7) & 0,167 & 0,177 & 0,179 & 0,217 & 0,253 & $0,274^{*}$ & 1,000 \\
\hline
\end{tabular}

${ }^{*} \mathrm{p}<0,05 ;{ }^{* *} \mathrm{p}<0,01$

Table 2: Factor analysis of buyer-supplier relationships

\begin{tabular}{|c|c|c|c|c|c|c|}
\hline Factor & Items & $\begin{array}{l}\text { Factor } \\
\text { loadings }\end{array}$ & Eigenvalue & $\begin{array}{c}\text { Percentage of } \\
\text { variance explained }\end{array}$ & $\begin{array}{l}\text { Cumulate } \\
\text { percentage } \\
\text { explained }\end{array}$ & Cronbach's \\
\hline \multirow{3}{*}{$\begin{array}{l}\text { Purchasing } \\
\text { cooperative } \\
\text { relationship }\end{array}$} & Long-term relationship & 0,739 & & & & \\
\hline & $\begin{array}{l}\text { Open communications and } \\
\text { information sharing }\end{array}$ & 0,675 & & & & \\
\hline & $\begin{array}{l}\text { Quality focus in selecting suppliers } \\
\text { JIT purchasing }\end{array}$ & $\begin{array}{l}0,673 \\
0,597\end{array}$ & 3,167 & 63,3 & 63,3 & 0,7749 \\
\hline \multirow{2}{*}{$\begin{array}{l}\mathrm{R} \& \mathrm{D} \text { cooperative } \\
\text { relationship }\end{array}$} & Supplier development & 0,595 & 1,357 & 27,2 & 90,5 & 0,7912 \\
\hline & $\begin{array}{l}\text { Supplier involvement in product } \\
\text { development } \\
\text { Reduced number of suppliers* }\end{array}$ & 0,562 & & & & \\
\hline
\end{tabular}


Table 3: Factor analysis of manufacturing performance

\begin{tabular}{|c|c|c|c|c|c|c|}
\hline Name given & Items & $\begin{array}{l}\text { Factor } \\
\text { loadings }\end{array}$ & Eigenvalue & $\begin{array}{c}\text { Percentage of } \\
\text { variance explained }\end{array}$ & $\begin{array}{c}\text { Cumulate } \\
\text { percentage } \\
\text { explained }\end{array}$ & Cronbach's \\
\hline \multirow{4}{*}{ Quality } & Product reliability & 0,868 & \multirow{4}{*}{30,58} & \multirow{4}{*}{55,23} & \multirow{4}{*}{55,23} & \multirow{4}{*}{0,8909} \\
\hline & Product performance & 0,774 & & & & \\
\hline & Product features & 0,753 & & & & \\
\hline & Conformance to specifications & 0,655 & & & & \\
\hline \multirow{4}{*}{ Cost } & Equipment utilization & 0,879 & \multirow{4}{*}{18,84} & \multirow{4}{*}{34,03} & \multirow{4}{*}{89,26} & \multirow{4}{*}{0,8398} \\
\hline & Production costs & 0,774 & & & & \\
\hline & Inventory & 0,753 & & & & \\
\hline & Labor productivity & 0,655 & & & & \\
\hline \multirow{3}{*}{ Delivery } & Delivery dependability & 0,872 & \multirow{3}{*}{3,95} & \multirow{3}{*}{7,13} & \multirow{3}{*}{93,21} & \multirow{3}{*}{0,8162} \\
\hline & Delivery speed & 0,729 & & & & \\
\hline & Production lead time & 0,538 & & & & \\
\hline \multirow{5}{*}{ Flexibility } & Mix flexibility & 0,945 & \multirow{5}{*}{1,25} & \multirow{5}{*}{2,26} & \multirow{5}{*}{95,47} & \multirow{5}{*}{0,9138} \\
\hline & Changeover flexibility & 0,941 & & & & \\
\hline & Volume flexibility & 0,883 & & & & \\
\hline & Process flexibility & 0,867 & & & & \\
\hline & Modification flexibility & 0,72 & & & & \\
\hline
\end{tabular}

The reasons for choosing four factors were: (1) the 'eigenvalue greater than 1' rule pointed to four factors; (2) the four-factor solution accounted for $95.47 \%$ of the variance; and (3) the Cronbach alphas for each factor, which were quality (0.8909), cost (0.8398), delivery (0.8162) and flexibility (0.9138). The results confirmed the reliability of the manufacturing performance ratings.

The two dimensions of buyer-supplier relationships (the purchasing cooperative relationship and $R \& D$ cooperative relationship) were treated as independent factors. The four manufacturing performance factors were treated as dependent factors, and were referred to as quality, cost, delivery and flexibility, respectively. The factor score for the purchasing cooperative relationship factor was then correlated with the four manufacturing performance factor scores, as shown in Table 4. These correlations were equivalent to standardized betas from a regression of the purchasing cooperative relationship factors on the four manufacturing performance factor scores. The purchasing cooperative relationship factor was significantly associated with quality and delivery but was not significantly correlated with cost and flexibility. A similar correlation analysis was performed on the $R \& D$ cooperative relationship factor and manufacturing performance factor scores. Table 4 shows that the R\&D cooperative relationship factor was significantly associated with cost, delivery and flexibility but was not significantly correlated with quality.

\section{Discussion}

\section{The dimensions of purchasing cooperative} relationships

This dimension represents purchasing cooperative relationships. As Taiwanese machine tool plants often utilize JIT purchasing and long-term relationships, the two- way sharing of information, and quality are important factors when selecting suppliers for the integration of purchasing operations.

Top management regularly meets to increase the supplier's understanding of the selected strategies and create confidence in the information provided by the plant/supplier. Two-way information sharing is accomplished when top management holds regular meetings to monitor what has been accomplished, and the frequency of face-to-face communication, telephone and Electronic Data Interchange (EDI) communication and the distribution of published technical documents provide opportunities at the operating level for the exchange of information. The quality of the suppliers is reinforced through the assessment of the supplier's performance using formal and sophisticated evaluation according to established guidelines and procedures, in addition to the use of a supplier quality audit program to certify the supplier's quality and performance.

Table 4 presents the correlations of the purchasing cooperative relationship factors for the quality and delivery factor scores. The use of formal, sophisticated evaluation and quality audit programs ensure the selection of qualified key component suppliers that can meet the quality requirements of the customers. The JIT purchasing system involves a reduction in quantity per shipment and an increase in the frequency of supplies through the pull (kanban) procurement system, using long-term relationships with suppliers that are geographically close to the plants and that can meet the time requirements of the customers. The plants communicate and share information concerning quality and technical aspects with these qualified suppliers for frequent and reliable deliveries, which are rigorously synchronized with the plant's production schedule. 
Table 4: Correlation analysis of buyer-supplier relationships with manufacturing performance

\begin{tabular}{l|c|c|c|c}
\hline \multicolumn{1}{c|}{ Independent variables: } & \multicolumn{3}{c}{ Dependent variables: } \\
\multirow{2}{*}{ Quality } & Cost & Delivery & Flexibility \\
\hline Purchasing cooperative relationship & $\mathrm{r}=0,347^{*}$ & $\mathrm{r}=0,213$ & $\mathrm{r}=0,350^{*}$ & $\mathrm{r}=0,215$ \\
\hline $\mathrm{R} \& \mathrm{D}$ cooperative relationship & $\mathrm{r}=0,246$ & $\mathrm{r}=0,435^{* *}$ & $\mathrm{r}=313$ & $\mathrm{r}=0,443^{* *}$ \\
\hline${ }^{*} \mathrm{p}<0,01,{ }^{* *} \mathrm{p}<0,001$ &
\end{tabular}

The lack of a significant correlation with cost and flexibility was explained as follows. Firstly, higher manufacturing costs are created by maintaining multiple sources of supply and key component suppliers. Secondly, since the quality focus used when selecting suppliers causes the products to be dominated by the key component suppliers, plants cannot modify specifications by themselves. If they want to add additional functions to increase the added value of their product, they must rely on these suppliers. It could be seen that Taiwan machine tool companies have high homogeneity and cause the products to have little flexibility.

\section{The dimensions of $R \& D$ cooperative relationships}

This dimension represents $\mathrm{R} \& \mathrm{D}$ cooperative relationships, with the plants helping their suppliers improve production performance to enhance the involvement of suppliers in the plant's new product development. The following are important and common practices of $\mathrm{R} \& \mathrm{D}$ cooperative relationships in the Taiwanese machine tool industry. The involvement of the supplier in design activities involves design simplification and product modularization, component standardization, the choice of material, production cycles and processes. Supplier development activities consist of site visits and training or education, which provide advisory assistance concerning equipment, operating methods and quality systems to increase the supplier's awareness and help the supplier improve its capabilities.

Table 4 presents the correlations of the R\&D cooperative relationship factor to the three manufacturing performance factor scores, namely, cost, delivery and flexibility. First, the supplier developers within the machine tool plants allocate training and technical resources to develop and align specific R\&D capabilities, both internally and at their suppliers' facilities, to improve the efficiency of a production line and achieve lower cost. The supplier's technical advice and assistance could generate improved component designs, reduce development cost and achieve higher productivity. Second, in new product development phases, suppliers take responsibility for process development to identify the supplier's technical problems and find more efficient ways of working together to reduce the overall development time in order to meet the expectations of customers. Finally, supplier-originated ideas and technologies can standardize and modularize the components, creating process and products with flexibility. Thus, R\&D cooperative relationships are significantly associated with the three manufacturing performances of cost, delivery and flexibility.
The lack of significant correlation with quality is due to the fact that the machine tool industry is a capital and technology-intensive industry. In the pursuit of higher quality, machine tool companies need significant financial benefits in addition to practice and experience. Since the plants are small and median enterprises (SME) and these supplier scale are less than plants, it is difficult to develop suppliers to suppliers' capabilities. The contributions to supplier development are limited in terms of training and the technical resources needed for achieving quality. During new product development stages, suppliers only take responsibility for process development. The overall objective of process development is to reduce manufacturing costs, achieve shorter term or even immediate responsiveness, and make products with more flexibility and higher quality for both parties. Moreover, in this research, it agrees the prior research. It points out further that buy-supplier relationship could be divided into two kinds of relationships. These two relationships have different significant relationship with performance.

\section{Conclusions}

The study contributed to linking the areas of buyer-supplier relationships and manufacturing performance through identifying an appropriate set of buyer-supplier relationships from a review of the literature. This study examined a comprehensive set of seven buyer-supplier relationships and four manufacturing performance factors. It was proposed that there is an underlying pattern of deploying buyer-supplier relationships in the Taiwanese machine tool industry, and a factor analysis of these seven items provided empirical support for buyer-supplier relationships as having two dimensions. Specifically, the two core dimensions of the buyer-supplier relationships identified were:

(1) Purchasing cooperative relationships, consisting of long-term relationships with open communication and the sharing of information, and with quality as the focus when selecting suppliers, and with JIT purchasing.

(2) R\&D cooperative relationships, consisting of supplier development and supplier involvement in product development.

The results suggested that the core dimensions of buyersupplier relationships might be different from what some authors have suggested. According to Manoochehri (1984), the coordinated effort of the Big Three to reduce the number of first-tier suppliers and to drive continuous 
supply chain improvement through them suggests that it is appropriate to study upstream SCM practices in this industry from the perspective of key first-tier suppliers. Then Scannell et al. (2000) suggested that long-term relationships, supplier development and JIT purchasing should load together. However, in this study, long-term relationships and JIT purchasing loaded together on the purchasing cooperative relationship factor, but supplier development loaded on the $R \& D$ cooperative relationship factor. These results were also inconsistent with Shin et al. (2000), who stated that long-term relationships, supplier development, a focus on quality when selecting suppliers, supplier involvement and a reduced number of suppliers should all load together. However, in this study, long-term relationships, a focus on quality when selecting suppliers and JIT purchasing loaded together on the purchasing cooperative relationship factor, and that supplier development and supplier involvement loaded on the R\&D cooperative relationship factor. Moreover, a reduced number of suppliers could not make the cut-off $(0.5)$ for these two factors. The results supported the statement that companies striving to maximize their own performance use a variety of interrelated tools and techniques, and the effectiveness of any one of these buyer-supplier relationships is enhanced by the complementary use of others (Toni \& Nassimbeni, 1999). It should also be noted that it is possible for industry differences to have an impact on the nature of underlying buyer-supplier relationship dimensions. These differences can yield a different number of factors and a different composition of items.

Moreover, buyer-supplier relationships were found to affect the manufacturing performance, which was inconsistent with Scannell et al. (2000) and Shin et al. (2000). Scannell et al. (2000) found that buyer-supplier relationships were significantly associated with delivery and quality performance but were not significantly correlated with cost and flexibility performance. Shin et al. (2000) also found that buyer-supplier relationships were significantly associated with cost, delivery and flexibility performance but were not significantly correlated with quality performance. However, in this study, all of the four manufacturing performance factors were significantly predicted by correlation analysis to have purchasing cooperative relationship factors and $R \& D$ cooperative relationship factors as independent variables. Two correlation analyses results showed that the purchasing cooperative relationship factor was significantly associated with quality and delivery but was not significantly correlated with cost and flexibility. The R\&D cooperative relationship factor was significantly associated with cost, delivery and flexibility but was not significantly correlated with quality. In other words, purchasing cooperative relationship factors and $\mathrm{R} \& \mathrm{D}$ cooperative relationship factors generally are positive contributors to manufacturing performance, but can vary depending on the dimensions of the buyer-supplier relationships. These findings support the predictive validity of the core dimensions of buyer-supplier relationships identified in this study. The SCM organization and procurement strategies of a particular enterprise play a major role in how the variables will influence the relationships. A Commodity team comprising the Buyer, QC, Production and R\&D members will have a very different relationship to one where everything is done via the Buyer.

This study provides several managerial implications for the Taiwanese machine tool industry. First, the results suggest that buyer-supplier relationships are important predictors of manufacturing performance. Second, the results for the four different aspects of manufacturing performance (quality, cost, delivery and flexibility) present actionable guidelines for plant managers. This type of information can help managers make effective use of limited resources. Last, with respect to competition within the Taiwanese machine tool industry, improvements need to be made to buyersupplier relationships in order to enhance the overall competitive performance.

\section{References}

Carr, A.S. \& Pearson, J.N. 1999. 'Strategically managed buyer-seller relationships and performance outcomes', Journal of Operations Management, 17: 497-519.

Choi, T.Y. \& Hartley, J.L. 1996. 'An exploration of supplier selection practices across the supply chain', Journal of Operations Management, 14: 333-43.

Dyer, J.H. \& Ouchi, W.G. 1993. 'Japanese-style partnerships: giving companies a competitive edge', MIT Sloan Management Review, 35(1):51-63.

De Toni, A. \& Nassimbeni, G. 1999. 'Buyer-supplier operational practices, sourcing policies and plant performance: result of an empirical research', International Journal of Production Research, 37(3): 597-619.

Ellram, L.M. 1995. 'Partnering pitfalls and success factors', International Journal of Purchasing and Materials Management, 31(Spring): 36-44.

Ellram, L.M. \& Hendrick, T.E. 1995. 'Partnering characteristics: A dyadic perspective', Journal of Business Logistics, 16(1): 41-64.

Gorton, M., Douarin, E., Davidova, S. \& Latruffe, L. 2008. 'Attitudes to agricultural policy and farming futures in the context of the 2003 CAP reform: A comparison of farmers in selected established and new member states', Journal of Rural Studies, 24: 322-36.

Hsieh, L.F. 2004. 'The buyer-supplier long-term partnership effects upon the buyer's operational performance in the Taiwan center-satellite factory system', International Journal of Technology Management, 28(2): 243-58.

Kekre, S., Murthi, B.P.S. \& Srinivasan, K. 1995. 'Operating decisions, supplier availability and quality: An 
empirical study', Journal of Operations Management, 12(3-4): 387-96.

Levy, D.L. 2008. 'Political contestation in global production network', The Academy of Management Review, 33(4): 943-63.

Manoochehri, G. 1984. 'Suppliers and the Just-In-Time concept', Journal of Purchasing and Materials Management, 20(1):16-21.

Miller, J.G. \& Roth, A.V. 1994. 'A taxonomy of manufacturing strategies', Management Science, 40(3): 285-303.

MIRL. 1998. 1998 Taiwan Yearbook of Machine Tools (in Chinese). Taiwan: Industrial Technology Research Institute.

Monczka, R.M. \& Morgan, J.P. 1993. 'Supply base strategies to maximize supplier performance', International Journal of Physical Distribution and Logistics Management, 23(4): 42-54.

Samson Wong, Y.M. 2005. 'Inter-organizational network and firm performance: The case of the bicycle industry in Taiwan', Asian Business \& Management, 4(1): 67-91.

Scannell, T.V., Vickery, S.K. \& Droge, C.L. 2000. 'Upstream supply chain management and competitive performance in the automotive supply industry', Journal of Business Logistics, 21(1): 23-48.

Shin, H., Collier, D.A. \& Wilson, D.D. 2000. 'Supply management orientation and supplier/buyer performance', Journal of Operations Management, 18(3): 317-33.

Steyn, P.D. \& Du Toit, A.S.A. 2010. 'Investigating the potential for the development of a just-in-time knowledge management model', South African Journal of Business Management, 41(2): 1-12.

Ministry of Finance, R.O.C. 2011. 'The statistics'. [online] URL:http://www mof.gov.tw/ctview.asp?xItem=61268\&ct Node=657. Accessed 01-Feb-2011.

Toni, A. \& Nassimbeni, G. 1999. 'Buyer-supplier operational practices, sourcing policies and plant performance: Result of an empirical research', International Journal of Production Research, 37(3): 597619.

Wagner, S.M. \& Krause, D.R. 2009. 'Supplier development: Communication approaches, activities and goals', International Journal of Production Research, 47(12): 3161-3177.

World People News. 2010. 'The ranking of Taiwanese export and import are well done'. [online] URL: http://www.worldpeoplenews.com/news/3/2010-09/7960 .
Accessed 01-Feb-2011. 